\title{
Quantitative Analysis of Foraging Habitat Use by Ciconiiformes in the Upper Paraná River Floodplain, Brazil
}

\author{
Márcio Rodrigo Gimenes ${ }^{1 *}$ and Luiz dos Anjos ${ }^{2}$ \\ ${ }^{1}$ Universidade Estadual de Maringá; Av. Colombo, 5790; 87020-900; Maringá - PR - Brasil. ${ }^{2}$ Departamento de \\ Biologia Animal e Vegetal; Universidade Estadual de Londrina; C. P.: 6001; 86051-970; Londrina - PR - Brasil
}

\begin{abstract}
The aim of this study was to analyze the seasonal variations in habitat selection and abundance of Ciconiiformes species in four foraging habitats (rivers, channels, connected and disconnected lagoons) on the upper Paraná River floodplain, Brazil, and to conduct the surveys of wading birds in 2002 and 2003. The largest number of species and highest abundances of most species were observed in the connected lagoons. Snowy Egrets (Egretta thula), Wood Storks (Mycteria americana), Roseate Spoonbills (Platalea ajaja), and Jabirus (Jabiru mycteria) frequently used connected lagoons (habitat with the highest fish abundance) and abandoned the areas during floods, suggesting that they were able to find high quality patches for foraging. Cocoi Herons (Ardea cocoi), Great Egrets (Ardea alba), and Rufescent Tiger-Herons (Tigrisoma lineatum) used habitats with lower fish abundance and did not totally abandon these areas during floods, suggesting they were not dependent on high quality patches. Differences in foraging techniques and social behavior explained the difference between the two groups. The results showed that opportunism did not totally explain the foraging habitat selection and in low water level seasons there were higher differences in foraging behavior among the species.
\end{abstract}

Key words: Wading birds, Ciconiiformes, prey availability, floodplain, Paraná river

\section{INTRODUCTION}

The floodplains of the central/southern portion of South America are among the world's largest in size and in terms of their importance for the aquatic birds (Antas, 1994). The Paraná River is approximately $3800 \mathrm{~km}$ long and drains the southcentral part of South America (Agostinho et al., 1995). The Paraná River basin has suffered from strong human impacts, mainly deforestation and the construction of dams. The $230-\mathrm{km}$ stretch of river between the mouth of the Paranapanema River (its main tributary) and the town of Guaíra, Brazil, in the upper Paraná River is the only significant segment in Brazil that is free from dams (Agostinho et al., 1994). Although upstream dams have altered the natural river regime, the flood pulse is the principal factor acting on the communities of that area (Thomaz et al., 1997). On the east bank (State of Paraná) of this section of the river, with relatively high elevations, there are limited flooded areas and semideciduous forests have almost all been converted to pasture. On the west bank (State of Mato Grosso do Sul), with low land elevation, there is a fairly wellpreserved floodplain with numerous braided secondary channels, lagoons, and rivers (SouzaFilho and Stevaux, 1997).

*Author for correspondence: mrgimenes@ hotmail.com 
Wading birds (Ciconiiformes) are conspicuous elements of these ecosystems, fully adapted to the flood-drought cycle (Kushlan et al., 1985; González, 1996b), but sensitive to anthropogenic perturbations in the hydrologic regime (Russell et al., 2002). The results of previous studies have suggested that the spatio-temporal fluctuations in the populations and seasonal variation in the habitat used by the wading birds resulted from variation in water levels and prey availability (Smith, 1997a; Strong et al., 1997; Young and Chan, 1997; Gaines et al., 1998; Maccarone and Brzorad, 1998; Butler and Vennesland, 2000; Gaines et al., 2000; Wong et al., 2001; Tourenq et al., 2003). For foraging, most of these birds choose the areas with shallow water and high prey densities (Kushlan, 1976; Master et al., 1993; Battley et al., 2003) that tend to be ephemeral and irregularly distributed in the floodplains (Fasola, 1994). Thus, Ciconiiformes use an extensive area for foraging, frequently changing locales (Custer and Osborn, 1978; Hoffman et al., 1994). Consequently, the studies on Ciconiiformes habitat use must employ large spatio-temporal scales (McCrimmon et al., 1997; Strong et al., 1997). In addition, most Ciconiiformes prey primarily on the fishes (Del Hoyo et al., 1992), whose distribution is strongly influenced by water levels (Erwin, 1985; Gawlik, 2002).

This opportunistic way of habitat selection is commonly described in the wading bird literature (Fasola, 1986; 1994). However, more recent studies have observed important differences among the species (Smith, 1997b; Gawlik, 2002; Russell et al., 2002), and questions are arising on how hydrologic cycle and variation in prey availability influence the foraging behaviors. Consequently, the studies on foraging habitat selection by Ciconiiformes need more empiric information and must employ large spatiotemporal scales (McCrimmon et al., 1997; Strong et al., 1997).

In this study, the structure and composition of Ciconiiformes communities in foraging habitats on the floodplain of the upper Paraná River were analyzed, and seasonal variation in the habitat selection and abundance were examined. The results can help to understand whether in the wading bird communities, foraging habitat selection is really simply opportunistic or whether there are differences among the species, and how the hydrologic cycle influence this process. There have been few studies on Ciconiiformes in Brazil
(Willis, 1995; Petry and Hoffmann, 2002; Bouton and Frederick, 2003; Gimenes and Anjos, 2006; Mestre et al., 2007). But this is the first study to quantitatively analyze the use of foraging habitats by the community.

\section{MATERIALS AND METHODS}

\section{Study area}

The climate in the study area $\left(22^{\circ} 40^{\prime} \mathrm{S}\right.$ to $22^{\circ} 52^{\prime} \mathrm{S}$ and $53^{\circ} 12^{\prime} \mathrm{W}$ to $53^{\circ} 38^{\prime} \mathrm{W}$ ) is classified as tropicalsubtropical, with an average annual temperature of $22^{\circ} \mathrm{C}$ (summer average $26^{\circ} \mathrm{C}$ and winter average $19^{\circ} \mathrm{C}$ ) and an average annual rainfall of $1500 \mathrm{~mm}$ (Centrais Elétricas do Sul do Brasil, 1986). In 2002 and 2003, the water levels of the Paraná River were highest between mid-January and April, with several short-duration flood pulses. During the last half of 2003, the water level was slightly higher than in the same period of 2002, occasionally reaching $3.0-3.5 \mathrm{~m}$, when the water began to overflow the levee and connect the river to the lateral vegetation and some isolated lagoons (Fig. 1).

For data collecting, four habitats were selected where wading birds were known to forage, including rivers, channels (semi-lotic water bodies connecting two rivers or two stretches of the same river, between 20-30 $\mathrm{m}$ wide), disconnected lagoons (not connected to rivers or channels, except during floods), and connected lagoons (permanently connected to rivers or channels). The number of sampling units in each habitat category was 3, 4, 13 and 16, respectively (Fig. 2). These sampling units were randomly chosen among the units where fish sampling data was available. All the sampling units were perennial water bodies even in the dry season. The bank slopes are such that only the periphery is shallow enough to allow the presence of Ciconiiformes, even during the dry season. Different proportions of these water bodies are occupied by free-floating plants (Eichhornia crassipes and Salvinia auriculata), rooted plants (Eichhornia azurea and Polygonum acuminatum) and submerged plants (Utricullaria spp and Cabomba spp). The surrounding landscape is covered by the várzea (Panicum prionitis, Paspalum conspersum, Eleocharis spp, and Fimbristylis autumnalis) or by the forests (Cecropia pachystachya, Croton urucurana, Inga vera, and Peschiera australis) (Souza et al., 1997). 


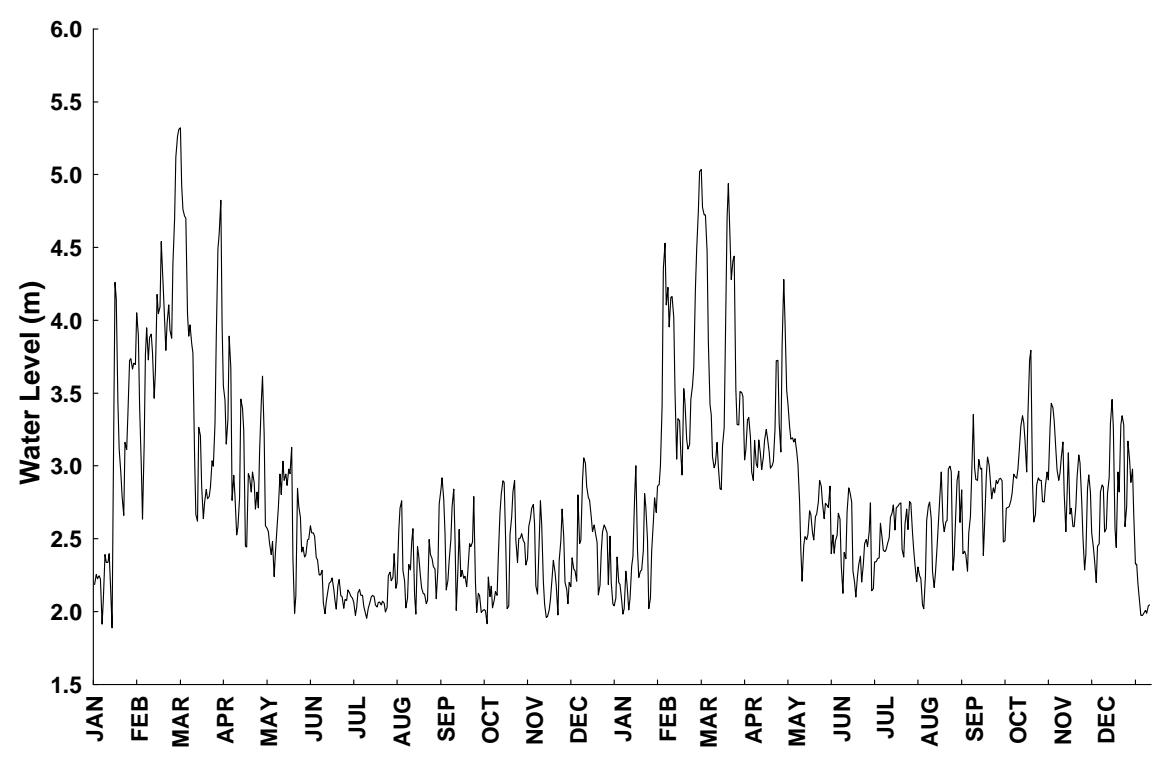

Figure 1 - Water level (depth) of upper Paraná River in the study area from January 2002 to December 2003. Data obtained from Porto São José Hydrometric Station.

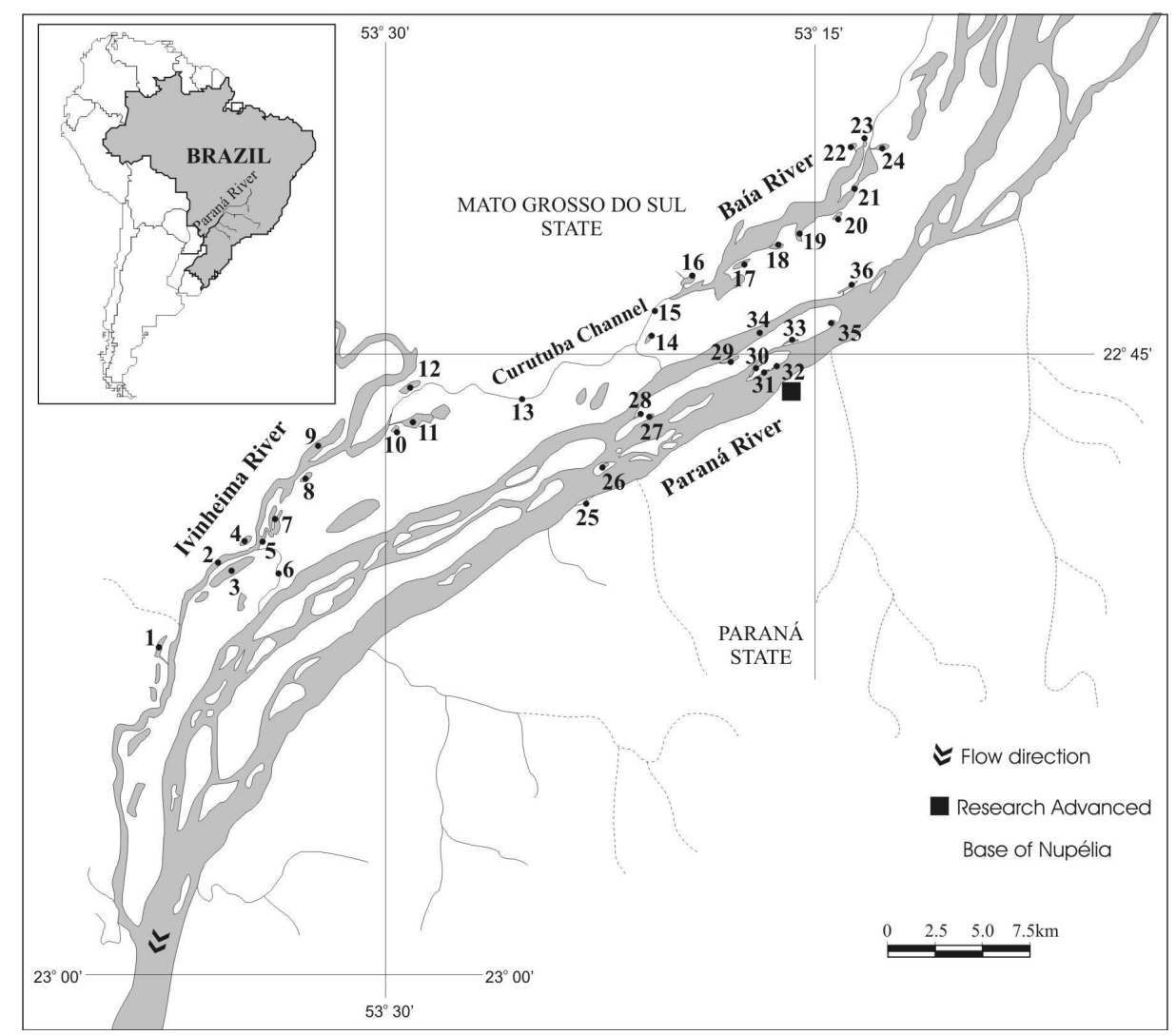

Figure 2 - Upper Paraná River floodplain with the location of the sampling units: rivers (2. Ivinhema, 15. Baía and 34. Paraná), channels (6, 13, 21 and 25), disconnected lagoons $(3,4,8,10,12,14,17,18,20,27,31,32$ and 35) and connected lagoons $(1,5,7,9$, $11,16,19,22,23,24,26,28,29,30,33$ and 36). 


\section{Fish abundance}

Data on fish abundance were obtained from the censuses of Long Term Ecology Monitoring Program - Site 6 of the Maringá State University. The bird and fish sampling were conducted during the same periods each year (see Bird surveys), except during the decreasing and increasing water seasons of 2003 when the fishes were not sampled. The fishes were sampled using seining nets (at the periphery of connected and disconnected lagoons) and gill nets (in deeper areas of rivers, connected, and disconnected lagoons). Fishes were not sampled in channels. Fishes abundance in the seining nets was expressed as density (number of fish per $100 \mathrm{~m}^{2}$ of sampling area), whereas the abundance in gill nets was expressed as capture per unit effort (CPUE), or the number of fishes per $1000 \mathrm{~m}^{2}$ net per $24 \mathrm{~h}$. Due to those different units, the results between the two methods could not be directly compared. Fishes abundance in the seining nets was a better parameter of fish availability because this method was used in low depth water. For the present study, only fishes up to $30 \mathrm{~cm}$ long were considered, approximately the maximum size captured by the largest Ciconiiformes species (Willard, 1985).

\section{Bird surveys}

Birds were surveyed in 2002 and 2003, according to the season of hydrological regime: flood (March), decreasing water level (May), dry (July), and increasing water level (December). In each period, two 1-h surveys were conducted on each sampling unit. The surveys were conducted either by the boat (connected lagoons, rivers and channels), or on foot (disconnected lagoons), identifying and recording each sighted bird (Bibby et al., 1992). Each transect began one hour after sunrise. All the individuals in or near (within $5 \mathrm{~m}$ ) the water bodies were recorded. Birds in the flight were only counted if they had been observed leaving the lagoon or landing in it. All the water bodies were sampled entirely, except the rivers. Distances from line transect were not determined.

\section{Analysis}

The $G$ test was used to analyze if there was significant difference in the abundance of fishes between the different sampling periods.
The structure and composition of wading bird communities were analyzed with Detrended Correspondence Analysis - DCA (Gauch, 1986; Jongman et al., 1995), applied to the abundance data (number of records/hr) of the species of Ciconiiformes in the sampling units in each one of the eight study periods and with the total abundance of each sampling unit (sum of nine DCAs). The first two axes were retained for interpretation because they explained most of the data variability. Calculations were made using the PC-ORD software (McCune and Mefford, 1997). Unifactorial analyses of variance (ANOVA unifactorial) was applied on the scores of the axes of DCA retained for interpretation, using the four habitats categories as factors to verify if the positioning of the habitats differed in the ordination. Post-hoc tests (Tukey) were used when ANOVA was significant to identify the habitats that presented different scores means in terms of positioning in the ordination. When DCAs scores did not meet the assumptions of a normal distribution (Shapiro-Wilk test) and variance homogeneity (Levene test) necessary for ANOVA, non-parametric variance analysis was used (Kruskal-Wallis test), followed by the test of multiple comparisons for non-parametric data of samples with different sizes (Dunn test). The G test was used to analyze if there was significant difference in the abundance of each bird species between the different sampling periods. An $\alpha-$ level of 0.05 was used in all analyses.

The habitat selection during different seasons was compared using Ivlev's selectivity index, modified by Jacobs (1974) and used by Fasola (1986) and Wong et al. (2001) to evaluate the habitat selection by herons and egrets: $E=(r-p) /(r+p)$, where " $r$ " is the ratio between the number of birds in the habitat and the total number of birds, and " $p$ " is the ratio between the surface area of the habitat and the total surface area available. "E" varies from -1 (negative selection) to +1 (positive selection); the values near 0 reflect use of habitat in proportion to their availability. The values above of 0.3 and below of -0.3 were arbitrarily considered significant. Due to the depth, the foraging activity for most species was limited to the periphery, and there was a stronger association between the total abundance (pooled for all counts) and the perimeter of the sampling areas 
(lagoons, rivers, and channels; Pearson, $r=0.64$; $P<0.001)$ than between the abundance and area (Pearson, $r=0.60 ; P<0.001$ ). Thus, the perimeter of lagoons and the sampled distance of rivers and channels multiplied by two were used as the measures of habitat availability (channels: 68.58 $\mathrm{km}$, rivers: $38.99 \mathrm{~km}$, connected lagoons: 50.92 $\mathrm{km}$, and disconnected lagoons: $14.18 \mathrm{~km}$ ). The area, perimeter, and length of the water bodies were obtained from the aerial photos (Souza-Filho and Stevaux, 2002).

\section{RESULTS}

\section{Fish abundance}

With seining nets, higher densities of fishes were always detected in the connected lagoons when compared to the disconnected lagoons. There was significant difference during the dry of both years ( $G=87.4$ and 58.1, respectively; $P<0.05)$ and during increasing water level season $(G=92.4 ; P$ $<0.05)$. However, during the decreasing water level season 2002 and flood of both years, fish densities were lower and similar between the two habitat types $(G=10.1,7.8$ and 8.1, respectively; $P>0.05)$. There was strong increase in fish density during the decreasing water level season of 2002 relative to the previous period. During the dry and increasing water level seasons of 2002, the density progressively decreased in the disconnected lagoons (Fig. 3a). With gill nets, the CPUE was also lowest overall during the flood of both years, and increased during the decreasing water level season of 2002 (except in the rivers). Later, there was an accentuated decrease in CPUE values in the disconnected lagoons (Fig. 3b).
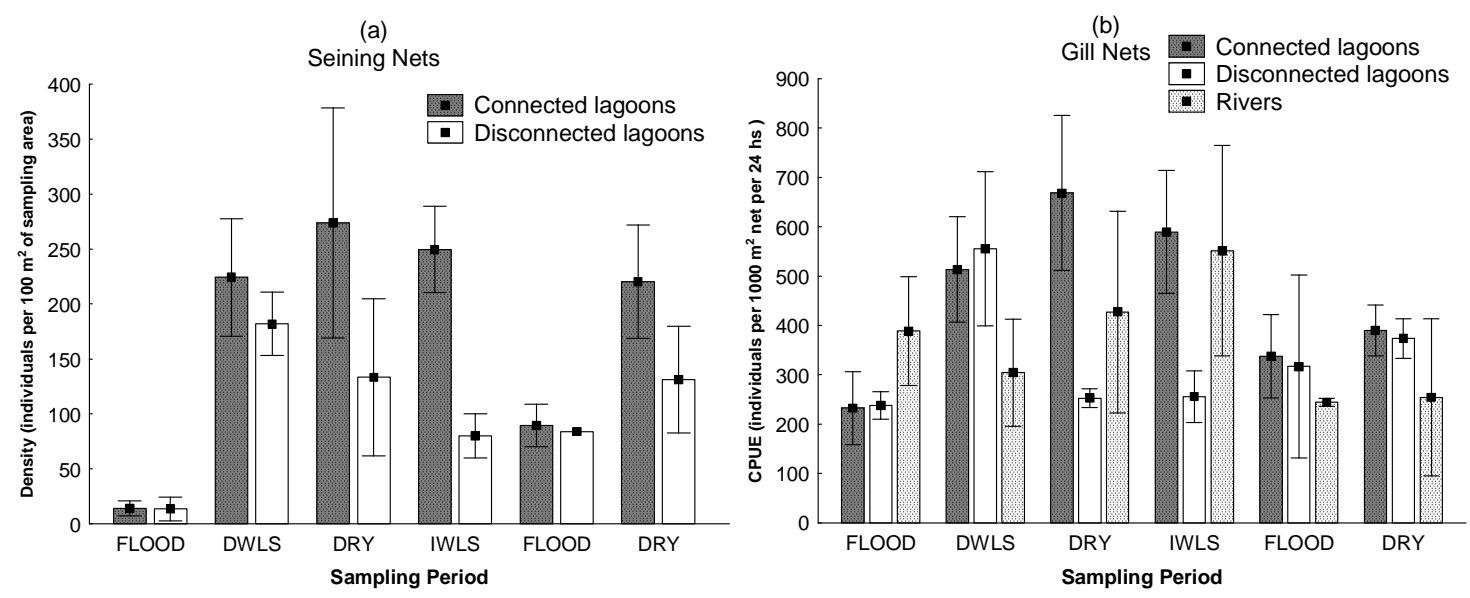

Figure 3 - Seasonal variation in the mean density and CPUE $( \pm$ SE) of fish collected in seining nets and gill nets, respectively, from Ciconiiformes foraging habitats. DWLS: decreasing water level season; IWLS: increasing water level season.

\section{Wading birds community structure and composition}

Fifteen species of wading birds were observed in the upper Paraná River floodplain (Table 1). Capped Herons (Pilherodius pileatus) were not observed at the sampling units and, therefore, were not included in the analyses. Of the 14 observed species, 13 were on connected lagoons, 11 on channels, eight on disconnected lagoons, and seven on rivers. Because Cattle Egrets (Bubulcus ibis), Whistling Herons (Syrigma sibilatrix), and Buff-necked Ibises (Theristicus caudatus) typically foraged in upland locations (Kushlan et al., 1985; Del Hoyo et al., 1992; Frederick and Bildstein, 1992), these were not included in the multivariate analyses. 
Table1 - Seasonal variation of the Ivlev's selectivity index, of number of records (in parentheses) and of number of species of Ciconiiformes (at the bottom of the table) registered in the different habitat categories (CL: connected lagoons; DL: disconnected lagoons; RI: rivers; $\mathrm{CH}$ : channels) during the study period. Significant values of Ivlev's selectivity index were in bold.

\begin{tabular}{|c|c|c|c|c|c|c|c|c|c|c|c|c|c|c|c|c|c|}
\hline & & \multicolumn{4}{|c|}{ FLOOD } & \multicolumn{4}{|c|}{ DECREASING WATER LEVEL } & \multicolumn{4}{|c|}{ DRY } & \multicolumn{4}{|c|}{ INCREASING WATER LEVEL } \\
\hline & & $\mathrm{CL}$ & DL & RI & $\mathrm{CH}$ & $\mathrm{CL}$ & DL & RI & $\mathrm{CH}$ & $\mathrm{CL}$ & DL & RI & $\mathrm{CH}$ & $\mathrm{CL}$ & DL & RI & $\mathrm{CH}$ \\
\hline \multirow[t]{2}{*}{$\begin{array}{l}\text { Ardea cocoi } \\
\text { (Cocoi Heron) }\end{array}$} & 2002 & $0.2(12)$ & $0.3(5)$ & $-0.2(5)$ & $-0.2(8)$ & $0.4(55)$ & 0 (7) & $-0.6(5)$ & $-0.4(14)$ & $0.3(45)$ & $0.1(9)$ & $-0.7(4)$ & $0(33)$ & $0.3(80)$ & $0(11)$ & $-0.5(11)$ & $\begin{array}{l}-0.3 \\
(31)\end{array}$ \\
\hline & 2003 & $0.2(26)$ & $-0.2(3)$ & $-0.7(2)$ & $0.1(27)$ & $0.3(40)$ & $0.2(9)$ & $-0.7(3)$ & $-0.1(26)$ & $0.3(29)$ & $0.1(5)$ & $-0.6(3)$ & $-0.1(18)$ & $0(29)$ & $0.6(27)$ & $-0.7(3)$ & $-0.1(33)$ \\
\hline \multirow[t]{2}{*}{$\begin{array}{l}\text { Ardea alba } \\
\text { (Great Egret) }\end{array}$} & 2002 & $0.3(11)$ & $0.3(3)$ & -1.0 & $-0.3(4)$ & $0.3(16)$ & $-0.1(2)$ & -1.0 & $0(11)$ & $0.219)$ & $0.4(7)$ & $-0.4(4)$ & $-0.3(9)$ & $0.4(25)$ & $0.1(4)$ & -1.0 & $\begin{array}{l}-0.2 \\
(10)\end{array}$ \\
\hline & 2003 & $0(2)$ & $0.6(2)$ & $-0.2(1)$ & $-0.2(2)$ & $0.4(43)$ & $0.1(7)$ & $-0.8(2)$ & $-0.4(12)$ & $0.320)$ & $0.5(9)$ & -1.0 & $-0.3(8)$ & $0.4(55)$ & $0.4(16)$ & -1.0 & $-0.7(5)$ \\
\hline Egretta thula & 2002 & $0.3(2)$ & -1.0 & $0.1(1)$ & $-0.2(1)$ & $0.4(84)$ & $0.1(12)$ & $-0.5(9)$ & $-0.6(12)$ & $0.5(138)$ & $-0.3(7)$ & $-0.5(14)$ & $-0.6(17)$ & $0.5(44)$ & -1.0 & $-0.4(5)$ & -1.0 \\
\hline (Snowy Egret) & 2003 & -1.0 & -1.0 & $0.6(3)$ & -1.0 & $0.4(119)$ & $-0.4(5)$ & $-0.6(8)$ & $-0.4(27)$ & $0.4(51)$ & $0.1(7)$ & $-0.5(6)$ & $-0.6(7)$ & $0.5(2)$ & -1.0 & -1.0 & -1.0 \\
\hline Bubulcus ibis & 2002 & - & - & - & - & - & - & - & - & - & - & - & - & - & - & - & - \\
\hline (Cattle Egret) & 2003 & -1.0 & $0.8(3)$ & -1.0 & -1.0 & - & - & - & - & $0.5(1)$ & -1.0 & -1.0 & -1.0 & - & - & - & - \\
\hline Syrigma sibilatrix & 2002 & - & - & - & - & - & - & - & - & - & - & - & - & - & - & - & - \\
\hline (Whistling Heron) & 2003 & - & - & - & - & $0.5(4)$ & -1.0 & -1.0 & -1.0 & - & - & - & - & -1.0 & -1.0 & -1.0 & $0.4(1)$ \\
\hline Butorides striata & 2002 & $0.3(105)$ & $0.1(17)$ & $-0.6(11)$ & $-0.2(48)$ & $0.4(44)$ & $-0.4(2)$ & $-0.4(6)$ & $-0.4(10)$ & $0.3(22)$ & $-0.6(1)$ & $-0.1(8)$ & $-0.2(12)$ & $0.4(243)$ & $-0.9(1)$ & $-0.5(25)$ & $-0.3(82)$ \\
\hline (Striated Heron) & 2003 & $0.3(87)$ & $-0.2(8)$ & $-0.5(12)$ & $-0.1(50)$ & $0.4(32)$ & $-0.3(2)$ & $-0.8(1)$ & $-0.2(11)$ & $0.4(31)$ & $0.5(10)$ & $-0.8(1)$ & -1.0 & $0.3(143)$ & $-0.3(10)$ & $-0.8(7)$ & $0(90)$ \\
\hline N. nycticorax & 2002 & $-0.4(5)$ & $-0.5(1)$ & -1.0 & $0.4(30)$ & $0.4(20)$ & -1.0 & $-0.3(3)$ & $-0.5(4)$ & $-0.3(1)$ & $0.8(5)$ & -1.0 & -1.0 & $-0.1(12)$ & -1.0 & $0.4(29)$ & $-0.3(12)$ \\
\hline $\begin{array}{l}\text { (Black-crowned } \\
\text { Night-Heron) }\end{array}$ & 2003 & $-0.3(13)$ & $-0.2(4)$ & $-0.2(12)$ & $0.2(47)$ & $-0.8(2)$ & -1.0 & -1.0 & $0.4(56)$ & $0.4(2)$ & -1.0 & -1.0 & $-0.1(1)$ & $-0.2(5)$ & $-0.3(1)$ & $-0.3(3)$ & $0.2(14)$ \\
\hline Tigrisoma lineatum & 2002 & $-0.4(1)$ & $0.5(2)$ & -1.0 & $0.2(5)$ & 0 (9) & $0.1(3)$ & $-0.8(1)$ & $0.2(18)$ & $0.1(17)$ & $0.4(9)$ & -1.0 & $0.1(22)$ & $0.2(23)$ & $-0.1(4)$ & $-0.8(1)$ & $0.1(26)$ \\
\hline $\begin{array}{l}\text { (Rufescent Tiger- } \\
\text { Heron) }\end{array}$ & 2003 & $0.1(17)$ & $-0.4(2)$ & $-0.4(5)$ & $0.1(27)$ & $0.2(27)$ & $0(5)$ & $-0.4(5)$ & $-0.1(19)$ & $0(6)$ & $0.7(9)$ & $-0.4(2)$ & $-0.5(3)$ & $0.2(10)$ & $0.2(3)$ & -1.0 & $0.1(11)$ \\
\hline Mycteria americana & 2002 & - & - & - & - & - & - & - & - & $0.5(3)$ & -1.0 & -1.0 & -1.0 & $0.5(1)$ & -1.0 & -1.0 & -1.0 \\
\hline (Wood Stork) & 2003 & - & - & - & - & $0.4(12)$ & -1.0 & -1.0 & $-0.1(5)$ & -1.0 & $0.8(1)$ & -1.0 & -1.0 & - & - & - & - \\
\hline Ciconia maguari & 2002 & - & - & - & - & $0.5(1)$ & -1.0 & -1.0 & -1.0 & - & - & - & - & $0.5(1)$ & -1.0 & -1.0 & -1.0 \\
\hline (Maguari Stork) & 2003 & $0.5(2)$ & -1.0 & -1.0 & -1.0 & - & - & - & - & - & - & - & - & - & - & - & - \\
\hline Jabiru mycteria & 2002 & - & - & - & . & - & - & - & - & $0.5(1)$ & -1.0 & -1.0 & -1.0 & $0.5(4)$ & -1.0 & -1.0 & $-0.3(1)$ \\
\hline (Jabiru) & 2003 & - & - & - & - & $0.5(1)$ & -1.0 & -1.0 & -1.0 & - & - & - & - & -1.0 & -1.0 & -1.0 & $0.4(3)$ \\
\hline M. cayennensis & 2002 & -1.0 & -1.0 & -1.0 & $0.4(2)$ & - & - & - & - & - & - & - & - & $-0.3(1)$ & -1.0 & -1.0 & $0.4(5)$ \\
\hline (Green Ibis) & 2003 & $0.5(1)$ & -1.0 & -1.0 & -1.0 & - & - & - & - & - & - & - & - & - & - & - & - \\
\hline Platalea ajaja & 2002 & - & - & - & - & $0.5(2)$ & -1.0 & -1.0 & -1.0 & $0.5(7)$ & -1.0 & -1.0 & -1.0 & $0.5(14)$ & -1.0 & -1.0 & $-0.4(3)$ \\
\hline (Roseate Spoonbill) & 2003 & - & - & - & - & $0.5(41)$ & -1.0 & -1.0 & $-0.6(5)$ & - & - & - & - & - & - & - & - \\
\hline Theristicus & 2002 & - & - & - & - & - & - & - & - & - & - & - & - & -1.0 & -1.0 & $0.6(4)$ & -1.0 \\
\hline $\begin{array}{l}\text { caudatus } \\
\text { (Buff-necked Ibis) }\end{array}$ & 2003 & - & - & - & - & - & - & - & - & - & - & - & - & - & - & - & - \\
\hline Species number & 2002 & 6 & 5 & 3 & 7 & 8 & 5 & 5 & 6 & 9 & 6 & 4 & 5 & 11 & 4 & 5 & 8 \\
\hline & 2003 & 7 & 6 & 6 & 5 & 10 & 5 & 5 & 8 & 7 & 6 & 4 & 5 & 6 & 5 & 4 & 7 \\
\hline
\end{tabular}

The axis 1 of the DCA, running with the total abundance of each sampling unit, separated the most disconnected lagoons from other samplings units, having significant difference in the ordination (Kruskal-Wallis; $H=12.4 ; P=0.006$; Fig. 4a). The Dunn test indicated that the difference was between the disconnected and connected lagoons $(P=0.01)$. Snowy Egrets (Egretta thula), Striated Herons (Butorides striata), Wood Storks (Mycteria americana), and Roseate Spoonbills (Platalea ajaja) were more abundant on the connected lagoons, and Cocoi Herons (Ardea cocoi), Rufescent Tiger-Herons (Tigrisoma lineatum), and Great Egrets (Ardea $a l b a$ ) on the disconnected lagoons (Fig. 4b). There was no significant difference in axis 2 of the ordination (ANOVA; $F=0.6 ; P=0.6$ ).
When the DCAs were analyzed to the sampling period, five displayed no significant differences in the ordination. During the dry season of 2002, there was a significant difference in axis 1 of the ordination (Kruskal-Wallis; $H=11.18 ; P=0.01$; Fig. 4c). The Dunn test again indicated a difference between the connected and disconnected lagoons $(P=0.02)$. Cocoi Herons, Rufescent Tiger-Herons, and Black-crowned Night-Herons (Nycticorax nycticorax) were found primarily on the disconnected lagoons, and Snowy Egrets, Striated Herons, and Black-crowned NightHerons on the connected lagoons. Wood Storks, Jabirus (Jabiru mycteria), and Roseate Spoonbills were only observed on the connected lagoons during this period (Table 1 and Fig. 4d). There was no significant difference in axis 2 of the ordination (Kruskal-Wallis; $H=0.8 ; P=0.8$ ). 

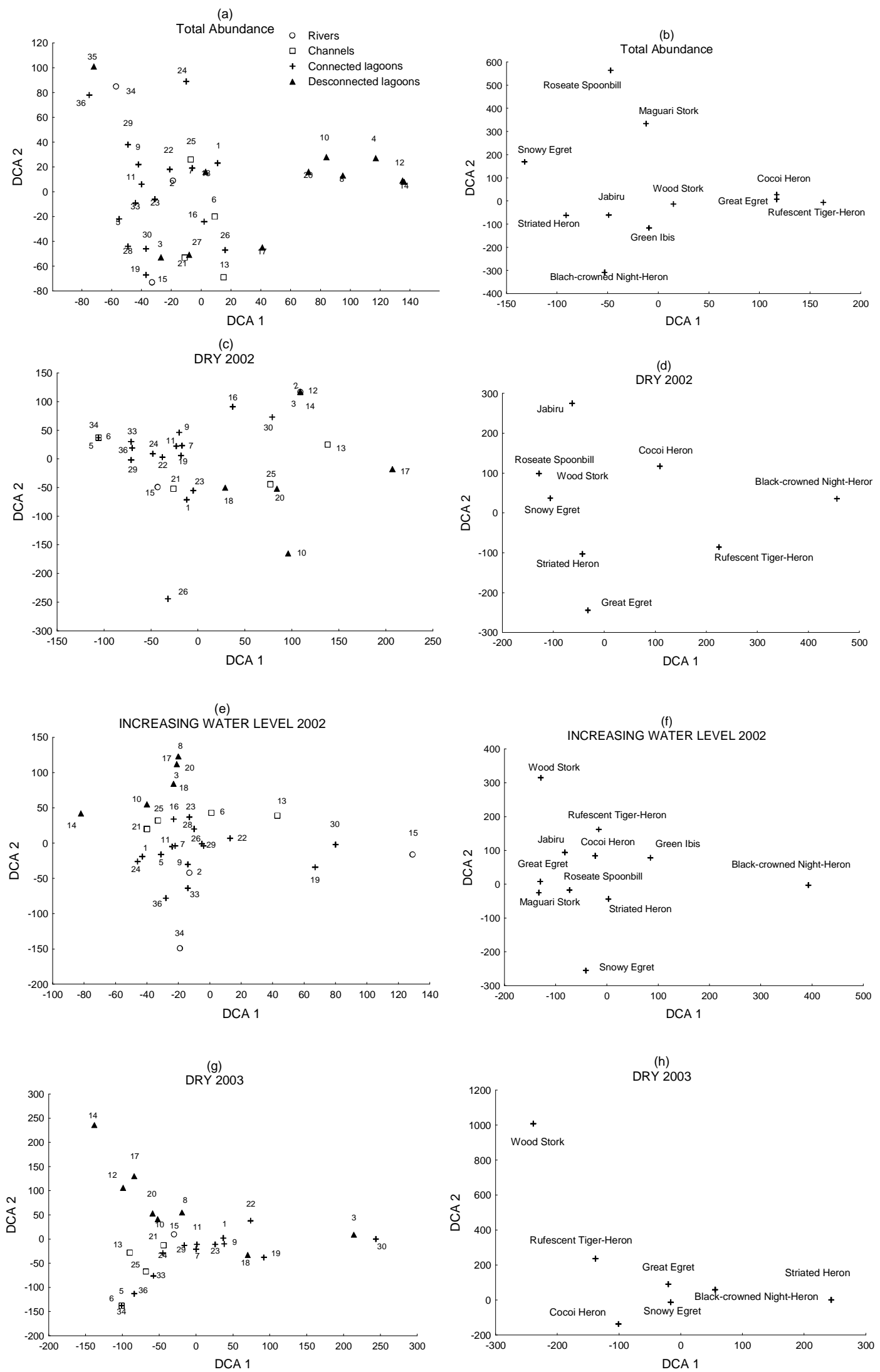

Figure 4 - Ordinations of Detrended Correspondence Analysis (DCA). The abundance of Ciconiiformes in the samplings units in each study period are depicted separately and with the total abundance of each sampling unit (local codes according to Fig. 2). 
During the increasing water level season of 2002, there was no difference in axis 1 of the ordination (Kruskal-Wallis; $H=4.5 ; P=0.21$ ), but there was a difference in axis 2 (Kruskal-Wallis; $H=21.1 ; P$ $=0.0001$; Fig. $4 \mathrm{e}$ ), with the Dunn test indicating a difference between the disconnected lagoons $(P=$ $0.004)$ and connected lagoons/rivers $(P=0.0008)$. Four species were observed on disconnected lagoons in low numbers, including Cocoi Herons, Great Egrets, and Rufescent Tiger-Herons. Relative to other habitats, connected lagoons were characterized by relatively high abundances of Snowy Egrets, Striated Herons, and Roseate Spoonbills and by the exclusive presence of Wood Stork and Maguari Stork (Ciconia maguari). The main species on the rivers were Striated Herons and Black-crowned Night-Herons (Table 1 and Fig. 4f).

During the dry season of 2003, there was no significant difference in axis 1 of the ordination (Kruskal-Wallis; $H=5.9 ; P=0.11$ ). There was a significant difference in axis 2 (ANOVA; $F=6.3$; $P=0.0027$; Fig. 4g), with the Tukey test indicating a difference between the disconnected lagoons $(P=0.02)$ and the connected lagoons/channels $(P=0.001)$. Most common species on disconnected lagoons were Rufescent Tiger-Herons. Snowy Egrets were more abundant on connected lagoons and Cocoi Herons on channels (Table 1 and Fig. 4h).

\section{Population fluctuation and habitat selection}

For all the habitats combined, seasonal variation in abundance was found. When the abundance of Snowy Egrets was high, the abundance of Striated Herons was low, and vice-versa. The variation in the abundance of Striated Heron $(G=633.6 ; P<$ $0.01)$ was similar both years, but Snowy Egrets $(G$ $=572.2 ; P<0.01)$ were more abundant during the dry and increasing water level seasons of 2002 than during similar periods of 2003 (Fig. 5a).

Cocoi Herons $(G=87.8 ; P<0.01)$ and Great Egrets $(G=97.1 ; P<0.01)$ displayed similar seasonal variation in abundance (Fig. $5 b$ ). In both years, Black-crowned Night-Heron $(G=148.3$; $P$ $<0.01$ ) declined in abundance from flood to dry seasons, but increased during the increasing water level season. Rufescent Tiger-Heron $(G=71.5 ; P$ $<0.01)$ displayed inconsistent seasonal variations in abundance across the two years. Green Ibises (Mesembrinibis cayennensis) $(G=19.9 ; P<0.01)$ were only observed during the flood and increasing water level seasons (Fig. 5c). Wood Storks $(G=54.7 ; P<0.01)$, Roseate Spoonbills $(G$ $=158.8 ; P<0.01)($ Fig. $5 \mathrm{~d})$ and Jabirus $(G=15.8$; $P<0.05$ ) (Fig. 5b) were observed during four of the eight periods and never during the flood season.

When the habitat use was compared to habitat availability, Ivlev's selectivity index showed that Snowy Egrets, Striated Herons, Wood Storks, and Jabirus typically used the connected lagoons more than other habitats. Maguari Storks and Roseate Spoonbills were only found in the connected lagoons (Table 1).

Cocoi Herons, Great Egrets, and Rufescent TigerHerons did not demonstrate clear preference for a particular habitat. All displayed a strong rejection for the rivers and, for Great Egrets and, to a smaller degree, Cocoi Herons also for the channels. These two species tended to prefer the lagoons, but varied in their preference between the connected and disconnected lagoons. Rufescent Tiger-Heron tended to use the channels, connected lagoons, and disconnected lagoons based on the availability. Black-crowned Night-Herons and Green Ibises tended to prefer the channels, except in the periods of low abundance for both the species (Table 1). 

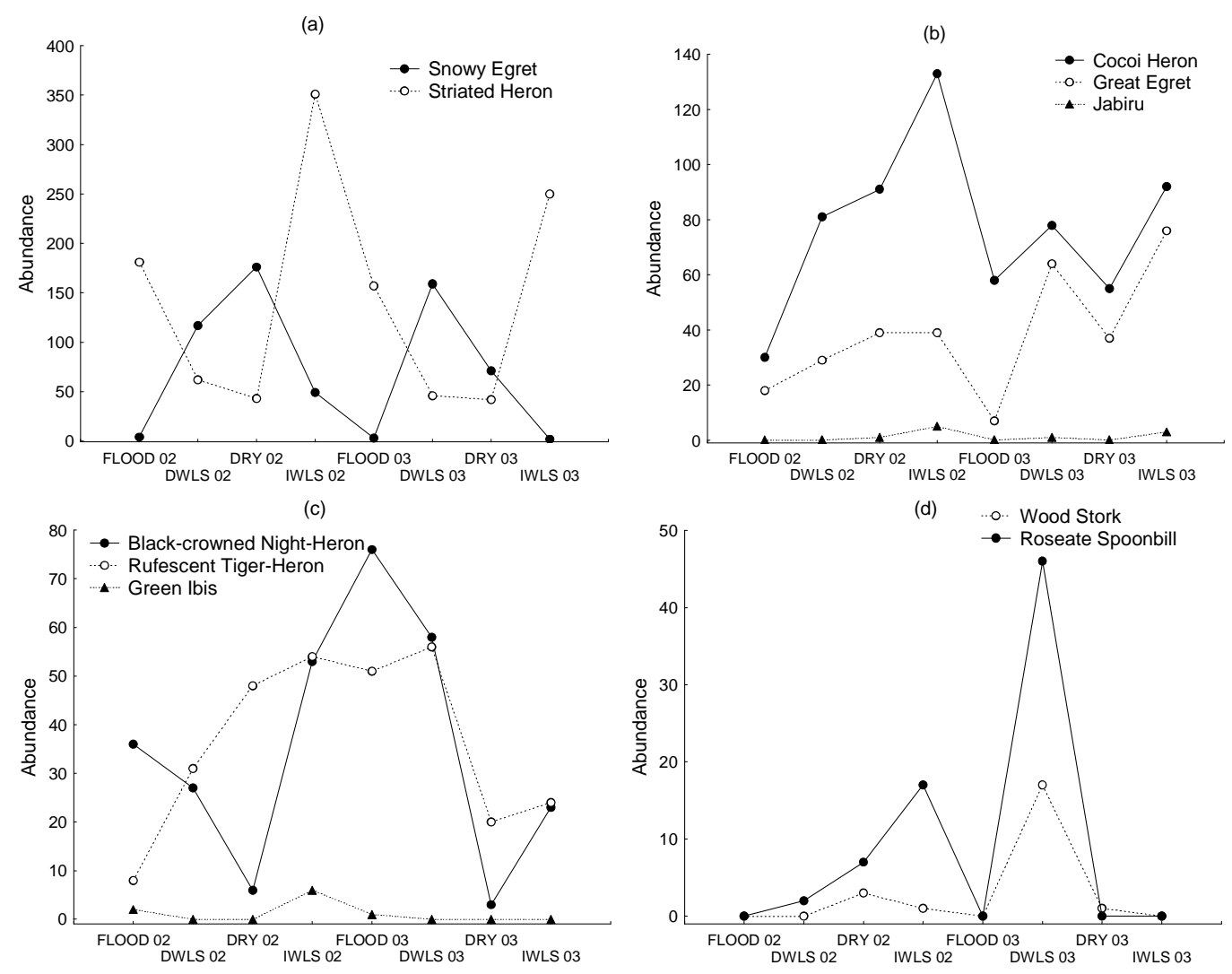

Figure 5 - Seasonal variation in the abundance (number of records) of the species of Ciconiiformes detected on the sampling units. All the habitat categories are displayed together. DWLS: decreasing water level season; IWLS: increasing water level season.

\section{DISCUSSION}

As a characteristic of floodplains, seasonal variation in water levels is a key factor in determining the ecological patterns in the study area (Junk et al., 1989). A flood period (constituted by irregular short-duration flood pulses) occurred in-between mid-January and April in both the years of this study. Although the fish productivity was highest in floodplains during a flood (Loftus and Eklund, 1994; Vazzoler et al., 1997), fishes were more dispersed, promoting homogeneity between the different habitats. Therefore, the low fish abundance in the water bodies during this period (which were very similar among the different habitats) fitted the expected pattern (probably fishes were more dispersed, no less abundant). With lower water levels, fish became more concentrated, promoting immediate increase in their availability during the decreasing water level season as well as greater differentiation between the habitats during the remainder of the year (i.e. as water bodies became isolated, colonization of disconnected lagoons became progressively less likely).

Results indicated that this process influenced the foraging habitat selection by the wading birds. The DCAs demonstrated that there were no significant differences among the habitat categories in the structure and composition of Ciconiiformes communities when the habitats were homogeneous (i.e., both during the flood and decreasing water level season, when the disconnected lagoons still had high fish abundance). The differences in the structure and composition of communities were detected during the dry and increasing water level seasons (i.e., when the disconnected lagoons were characterized by the progressive decreases in fish abundances). The occurrence of some pulses in the second half of 2003 might have prompted the migration of fishes from the rivers and channels to some disconnected lagoons and increased their 
abundance there, perhaps contributing to the present finding of no significant difference in DCA during the increasing water level season of that year. Herremans (1999) observed larger differences between the habitats in community composition of waterbirds during the dry season than during the wet season in humid areas of Botswana, when most species tended to group on the few high-quality patches, while others used a wide variety of habitats. Therefore, although opportunism is the predominant characteristic of Ciconiiformes, in certain environmental conditions it is possible to notice the differences between the species in selection of foraging habitats (Fasola, 1994; Smith, 1997b).

Among the studied habitats, the connected lagoons could be considered the higher-quality patches in terms of fish abundance, but caution should be warranted in this interpretation. On the same area, Gimenes and Anjos (2006) observed that the sampling with seining nets in the periphery of the lagoons yielded better estimates of prey availability for Ciconiiformes than sampling with gill nets in the deeper areas because fishes captured by each method were differentially vulnerable to predation by the birds. Furthermore, the rivers and channels were not sampled with seining nets, which limited the applicability of initial statement as above. However, the highest total richness, the highest total abundance, and the highest per-species abundances of bird species were recorded on the connected lagoons, which was a strong indication of the high quality of this habitat.

Snowy Egrets, Wood Storks, Roseate Spoonbills, and, to a lesser degree, Jabirus were more able to find high-quality patches for foraging, selecting connected lagoons and leaving the area during the floods when the high water level diminished appropriate foraging habitats. The species with tactile (Wood Stork and Roseate Spoonbill) or tactile-visual (Jabiru) foraging techniques were more dependent on the patches with low depth and high prey density than were species that forage visually (Kushlan et al., 1985; Gaines et al., 1998). Snowy Egret is often the first species to locate high-quality patches, acting as a catalyst for larger aggregations (Caldwell, 1981), on which it depends in the periods of high energetic demand (Erwin, 1985; Master et al., 1993). These four species have white or white-pink (Roseate Spoonbill) plumage and forage socially, two characteristics intimately related (Beauchamp and
Heeb, 2001). There are evidences that these characteristics reduce search time for high-quality patches, especially where resources are ephemeral and patchily distributed (Kushlan, 1976; 1981).

Great Egrets, Cocoi Herons, and Rufescent TigerHerons were apparently less able to find highquality patches, not selecting the connected lagoons and remained within the study site during the flood, although normally with, apparently, lower abundances. These species were primarily found on disconnected lagoons, where the fish abundance was low. These species are visual foragers, minimizing the negative effects of the low prey density (Kushlan et al., 1985). All of these employ passive foraging techniques and defend territories (Del Hoyo et al., 1992), characteristics of minimal utility in the aggregations that form on high-quality patches (Kushlan, 1978; 1981; Erwin, 1983). The long legs of Great Egrets and Cocoi Herons allow them to explore deeper sites and their relatively long bills allow them to capture a wide range of prey items (Kushlan, 1978). Gawlik (2002) found that Great Egrets and Great Blue Herons (Ardea herodias), a congener of Cocoi Herons, tended to remain on specific patches even when they decreased in quality.

Given the differences between the two groups of species, each is differently affected by anthropogenic alterations in habitat. High-quality patches (abundant fish and shallow water) are usually ephemeral, irregularly distributed, and occupy a small fraction of the landscape at any time. Thus, species more dependent on highquality patches are more susceptible to the reductions in the floodplain area or alterations of the hydrologic regime that reduce the quality of foraging sites. Not surprisingly, the populations of the four species in this study that were constrained in the habitat use were declining in large floodplains suffering from strong anthropogenic alterations, such as the Everglades (Hoffman et al., 1994; McCrimmon et al., 1997; Strong et al., 1997) and Venezuelan Llanos (González, 1996a; 1997).

The habitat selection by Maguari Storks and Striated Herons seemed to be more influenced by the prey density and less by water depth because these species clearly selected connected lagoons and used those areas during the floods. In the southern Llanos of Venezuela, González (1996b) observed that Maguari Stork maintained uniform density as the whole year, even during the floods. 
This species is solitary, forages visually and passively (Kushlan et al., 1985; Del Hoyo et al., 1992), and has long legs, characteristics that allow foraging in deeper water. In addition, Striated Herons frequently foraged on the dense surface mats of aquatic plants, allowing them to use the area during the floods.

Black-crowned Night-Herons and Green Ibises tended to select the channels for foraging, probably because these sites were near a continuous strip of riparian forest. Black-crowned Night-Herons are primarily nocturnal foragers and, because they often move long distances between the roost sites and foraging habitats (Custer and Osborn, 1978), it was not possible to determine if they also used the channels for foraging or just as a roost site. The lower abundance of the species during the dry season was likely due to the movement of individuals to breeding areas, as is known to occur in the Pantanal during that period (Willis, 1995).

When the habitat use was compared to habitat availability, the channels and rivers were used less than expected by most species. Caldwell (1986) found that several wading birds in Panama preferred lentic waters to more lotic waters, except if threatened by the predators, suggesting that foraging in lotic waters was more difficult.

These results indicated that the study area represented an important foraging area for the wading birds, despite recent anthropogenic impacts. The area might be particularly important for Wood Storks and Roseate Spoonbills, two species of high conservation value. The Pantanal population of Wood Storks abandons the area in November, in the beginning of the flood, using the Paraná River as a migration corridor to the flooded areas of Rio Grande do Sul and Argentina, and then returning in April or May (CEMAVE, unpubl. data). Antas (1994) reported that Roseate Spoonbills followed Wood Storks in that movement because the two species used similar foraging and breeding areas. The present study area might represent an important foraging area for these birds during migration.

The management strategies aiming to enhance the area as a foraging area for Ciconiiformes should try to maintain a hydrologic regime as similar as possible to the natural regime. The scarcity of appropriate foraging habitats and the low prey availability make the floodplain unsuitable to the wading birds during floods (Kushlan et al., 1985; Powell, 1987; Custer et al., 1996; Bjorklund and
Holm, 1997). However, it is important that floods occur normally (at the correct time and with normal water levels) to stimulate the fishes reproduction (Gomes and Agostinho, 1997) and the migration of alevin from the rivers to the lentic habitats that become alevins nurseries (Vazzoler et al., 1997). Finally, the natural progressive drying process on the floodplain that begins after the flood and proceeds until the end of the dry season should not be interrupted by artificial flood pulses because this interferes with the process of prey concentration in the water bodies.

\section{ACKNOWLEDGMENTS}

Financial support was provided by the Postgraduate in Freshwater Ecology (Maringá State University). MRG received Doctoral Scholarship from CNPq-Brazil and LdA received a Research Productivity grant from $\mathrm{CNPq}$ (350054/95-9). Sebastião Rodrigues, Leandro Rodrigues and Alfredo da Silva helped in field work. We appreciate the improvements in English usage made by Jen Johnson through the Association of Field Ornithologists' program of editorial assistance.

\section{REFERENCES}

Agostinho, A. A.; Julio Jr., H. F. and Petrere, Jr., M. (1994), Itaipu reservoir (Brazil): impacts of the impoundment on the fish fauna and fisheries. InRehabilitation of freshwater fisheries, ed. I. G. Cowx. Fishing News Book, Bodman, pp. 171-184.

Agostinho, A. A.; Vazzoler, A. E. A. M. and Thomaz, S. M. (1995), The high River Paraná Basin: limnological and ichtyological aspects. In- Limnology in Brazil, eds. J. G. Tundisi; C. E. M. Bicudo and T. Matsumura-Tundisi. ABC/SBL, Rio de Janeiro, pp. 59-103.

Antas, P. T. Z. (1994), Migration and other movements among the lower Paraná River valley wetlands, Argentina, and the south Brazil/Pantanal wetlands. Bird Conserv. Int., 4, 181-190.

Battley, P. F.; Poot, M.; Wiersma, P.; Gordon, C.; Ntiamoa-Baidu, Y. and Piersma, T. (2003), Social foraging by waterbirds in shallow coastal lagoons in Ghana. Waterbirds, 26: (1), 26-34.

Beauchamp, G. and Heeb, P. (2001), Social foraging and the evolution of white plumage. Evol. Ecol. Res., 3, 703-720.

Bibby, C. J.; Burgess, N. D. and Hill, D. A. (1992), Bird census techniques. Academic Press, London. 
Bjorklund, R. G. and Holm, D. J. (1997), Impact of flooding on Illinois river wading bird colonies. Trans. Ill. State Acad. Sci., 90, 123-133.

Bouton, S. N. and Frederick, P. C. (2003), Stakeholders' perceptions of a wading bird colony as a community resource in the Brazilian Pantanal. Conserv. Biol., 17, 297-306.

Butler, R. W. and Vennesland, R. G. (2000), Integrating climate change and predation risk with wading bird conservation research in North America. Waterbirds, 23 (3), 535-540.

Caldwell, G. S. (1981), Attraction to tropical mixedspecies heron flocks: proximate mechanisms and consequences. Behav. Ecol. Sociobiol., 8, 99-103.

Caldwell, G. S. (1986), Predation as a selective force on foraging herons: effects of plumage color and flocking. Auk, 103, 494-505.

Centrais Elétricas do Sul do Brasil (1986), Ilha Grande. Relatório de pesquisa. Florianópolis: ELETROSUL. v. 4.

Custer, T. W. and Osborn, R. G. (1978), Feeding habitat use by colonially-breeding herons, egrets, and ibises in north Carolina. Auk, 95, 733-743.

Custer, T. W.; Hines, R. K. and Custer, C. M. (1996), Nest initiation and clutch size of great blue herons on the Mississippi river in relation to the 1993 flood. Condor, 98, 181-188.

Del Hoyo, J.; Elliott, A. and Sargatal, J. (1992), Handbook of the birds of the world. Copyright Lynx Edicions, Barcelona. v. 1.

Erwin, R. M. (1983), Feeding habitats of nesting wading birds: spatial use and social influences. Auk, 100, 960-970.

Erwin, R. M. (1985), Foraging decisions, patch use and seasonality in egrets (Aves: Ciconiiformes). Ecology, 66: (3), 837-844.

Fasola, M. (1994), Opportunistic use of foraging resources by heron communities in southern Europe. Ecography, 17, 113-123.

Fasola, M. (1986), Resource use of foraging herons in agricultural and nonagricultural habitats in Italy. Colon. Waterbirds, 9, 139-148.

Frederick, P. C. and Bildstein, K. L. (1992), Foraging ecology of seven species of neotropical ibises (Threskiornithidae) during the dry season in the Llanos of Venezuela. Wilson Bull., 104 (1), 1-21.

Gaines, K. F.; Bryan Jr., A. L. e Dixon, P. M. (2000), The effects of drought on foraging habitat selection of breeding wood storks in coastal Georgia. Colon. Waterbirds, 23 (1), 64-73.

Gaines, K. F.; Bryan Jr., A. L.; Dixon, P. M. and Harris, M. J. (1998), Foraging habitat use by wood storks nesting in the coastal zone of Georgia, USA. Colon. Waterbirds, 21 (1), 43-52.

Gauch Jr., H. G. (1986), Multivariate analysis in community ecology. Cambridge University Press, Cambridge, UK.
Gawlik, D. E. (2002), The effects of prey availability on the numerical response of wading birds. Ecol. Monogr., 72, (3), 329-346.

Gimenes, M. R. and Anjos, L. (2006), Influence of lagoons size and prey availability on the wading birds (Ciconiiformes) in the upper Paraná river floodplain, Brazil. Arq. Biol. Tecnol, 49, 463-473.

Gomes, L. C. and Agostinho, A. A. (1997), Influence of the flooding regime on the nutritional state and juvenile recruitment of the curimba, Prochilodus scrofa, Steindachner, in upper Paraná river, Brazil. Fish. Manag. Ecol., 4, 263-274.

González, J. A. (1996a), Breeding biology of the Jabiru in the southern Llanos of Venezuela. Wilson Bull., 108, 524-534.

González, J. A. (1996b), Densidad y dinamica espaciotemporal de las poblaciones de cigüeñas (Ciconiidae) en los Llanos inundables de Venezuela. Orn. Neotrop., 7, 177-183.

González, J. A. (1997), Seasonal variation in the foraging ecology of the wood stork in the southern Llanos of Venezuela. Condor, 99, 671-680.

Herremans, M. (1999), Waterbird diversity, densities, communities and seasonality in the Kalahari Basin, Botswana. J. Arid Environ., 43, 319-350.

Hoffman, W., G. T. Bancroft and Sawicki, R. J. (1994), Foraging habitat of wading birds in the water conservation areas of the Everglades. In- Everglades: the ecosystem and its restoration, eds. S. M. Davis and J. C. Ogden. St. Lucie Press, Delray Beach, pp. 585-614.

Jacobs, J. (1974), Quantitative measurement of food selection. A modification of the forage ratio and Ivlev's electivity index. Oecologia, 14, 413-417.

Jongman, R. H. G., Braak, C. J. F. T. and Tongeren, O. F. R. V. (1995), Data analysis in community and landscape ecology. Cambridge University Press, Cambridge, UK.

Junk, W. J., Bayley, P. B. and Sparks, R. E. (1989), The flood pulse concept in river-floodplain systems. Can. Spec. Publ. Fish. Aquat. Sci., 106, 110-127.

Kushlan, J. A. (1978), Feeding ecology of wading birds. In- Wading birds, eds. A. Sprunt; J. C. Ogden and S. Winckler. Natl. Audubon Soc., New York, pp. 249297.

Kushlan, J. A. (1981), Resource use strategies of wading birds. Wilson Bull., 93: (2), 145-163.

Kushlan, J. A. (1976), Wading bird predation in a seasonally fluctuating pond. Auk, 93, 464-476.

Kushlan, J. A.; Morales, G. and Frohring, P. C. (1985), Foraging niche relations of wading birds in tropical wet savannas. In- Neotropical ornithology, eds. P. A. Buckley; M. S. Foster; E. S. Morton; R. S. Ridgely and F. G. Buckley. The American Ornithologists Union, Washington, pp. 663-682. 
Loftus, W. F. and Eklund. A. (1994), Long-term dynamics of an Everglades small-fish assemblage. InEverglades: the ecosystem and its restoration, eds. S. M. Davis and J. C. Ogden. St. Lucie Press, Delray Beach, pp. 461-484.

Maccarone, A. D. and Brzorad, J. N. (1998), The use of foraging habitats by wading birds seven years after the occurrence of major oil spills. Colon. Waterbirds, 21 (3), 367-374.

Master, T. L.; Frankel, M. and Russell, M. (1993), Benefits of foraging in mixed-species wader aggregations in a southern New Jersey saltmarsh. Colon. Waterbirds, 16: (2), 149-157.

McCrimmon Jr., D. A.; Fryska, S. T.; Ogden, J. C. and Butcher, G. S. (1997), Nonlinear population dynamics of six species of Florida Ciconiiformes assessed by Christmas bird counts. Ecol. Appl., 7, 581-592.

McCune, B. and Mefford, M. J. (1997), PC-ORD: Multivariate analysis of ecological data. Version 3.0. MjM Software Design, Oregon.

Mestre, L. A. M.; Krul, L. and Moraes, V. S. (2007), Mangrove bird community of Paranaguá Bay Paraná, Brazil. Arq. Biol. Tecnol, 50 (1), 75-83.

Petry, M. V. and Hoffmann, G. R. (2002), Ocupação e construção de ninhos em um ninhal misto de garças e maçaricos (Ciconiiformes) no Rio Grande do Sul. Biociências, 10, 55-63.

Powell, G. V. N. (1987), Habitat use by wading birds in a subtropical estuary: implications of hydrography. Auk, 104, 740-749.

Russell, G. J.; Bass Jr., O. L. and Pimm, S. L. (2002), The effect of hydrological patterns and breedingseason flooding on the numbers and distribution of wading birds in Everglades National Park. Anim.Conserv., 5, 185-199.

Smith, J. P. (1997a), An energy-circuit population model for great egrets (Ardea alba) at Lake Okeechobee, Florida, USA. Ecol. Model., 97,1-21.

Smith, J. P. (1997b), Nesting season food habits of 4 species of herons and egrets at Lake Okeechobee, Florida. Colon. Waterbirds, 20 (2), 198-220.

Souza, M. C.; Cislinski, J. and Romagnolo, M. B. (1997), Levantamento florístico. In- A Planície de Inundação do Alto Rio Paraná: aspectos físicos, biológicos e socioeconômicos, eds. A. E. A. M. Vazzoler; A. A. Agostinho and N. S. Hahn. EDUEM, Maringá, pp. 343-368.

Souza-Filho, E. E. and Stevaux, J. C. (1997), Geologia e geomorfologia do complexo rio Baía, Curutuba, Ivinheima. In- A Planície de Inundação do Alto Rio Paraná: aspectos físicos, biológicos $e$ socioeconômicos, eds. A. E. A. M. Vazzoler; A. A. Agostinho and N. S. Hahn. EDUEM, Maringá, pp. 346.
Souza-Filho, E. E. and Stevaux, J. C. (2002), Locais de amostragem. In- A planície Alagável do Alto Rio Paraná: estrutura e processos ambientais, eds. A. A. Agostinho, S. M. Thomaz, K. Nakatani, H. F. Júlio Jr., R. R. Antônio, K. D. G. Luz, F. C. Zavadski and J. L. L. Pereira. Relatório Técnico PELD/CNPq, Maringá, pp. 7-13.

Strong, A. M.; Bancroft, G. T. and Jewell, S. D. (1997), Hydrological constraints on tricolored heron and snowy egret resource use. Condor, 99, 894-905.

Thomaz, S. M.; Roberto, M. C. and Bini, L. M. (1997), Caracterização limnológica dos ambientes aquáticos e influência dos níveis fluviométricos. In- A Planície de Inundação do Alto Rio Paraná: aspectos físicos, biológicos e socioeconômicos, eds. A. E. A. M. Vazzoler; A. A. Agostinho and N. S. Hahn. EDUEM, Maringá, pp. 73-102

Tourenq, C.; Sadoul, N.; Beck, N.; Mesléard F. and Martin, J. L. (2003), Effects of cropping practices on the use of rice fields by waterbirds in the Camargue, France. Agric. Ecosyst. Environ., 95, 543-549.

Vazzoler, A. E. A. M.; Suzuki, H. I.; Marques, E. E. and Lizama, M. L. A. P. (1997), Primeira maturação gonadal, período e área de reprodução. In- A Planície de Inundação do Alto Rio Paraná: aspectos físicos, biológicos e socioeconômicos, eds. A. E. A. M. Vazzoler; A. A. Agostinho and N. S. Hahn. EDUEM, Maringá, pp. 249-265

Willard, D. E. (1985), Comparative feeding ecology of twenty-two tropical piscivores. In- Neotropical ornithology. Ornithological Monographs 36, eds. P. A. Buckley; M. S. Foster; E. S. Morton; R. S. Ridgely and F. G. Buckley. The American Ornithologists' Union, Washington, DC., pp. 788-797.

Willis, E. O. (1995), Black versus white waterbird colonies (Aves) in the Bolivian-Brazilian Pantanal. Iheringia, 78, 95-97.

Wong, L. C.; Corlett, R. T.; Young, L. and Lee, J. S. Y. (2001), Utilization of wetlands by ardeids in Starling Inlet, Hong Kong: a year-round study and a comparison between the census and flight-line methods. Waterbirds, 24 (1), 153-160.

Young, L. and Chan, G. (1997), The significance of drained fish ponds for wintering waterbirds at the Mai Po marshes, Hong Kong. Ibis, 139 (4), 694-698.

Received: July 04, 2009; Revised: October 05, 2009; Accepted: September 29, 2010. 